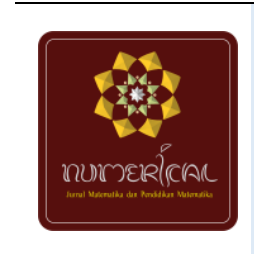

Vol. 3, No. 1, Juni 2019

Numerical: Jurnal Matematika dan Pendidikan Matematika

http://journal.iaimnumetrolampung.ac.id/index.php/numerical

DOI: https://doi.org/10.25217/numerical.v3i1.417

\title{
Pengembangan Bahan Ajar Aljabar Linear dengan Menggunakan Model Pembelajaran Matematika Knisley
}

\author{
Ria Anggraeni Syafnuri ${ }^{1}$, Netriwati ${ }^{2}$, Dona Dinda Pratiwi ${ }^{3}$
}

1,2,3 Pendidikan Matematika Universitas Islam Negeri Raden Intan Lampung Correspondence: $\nabla$ riasyafnuri@gmail.com

\begin{tabular}{|c|c|}
\hline Article Info & Abstract \\
\hline $\begin{array}{l}\text { Article History } \\
\text { Received : 24-02-2019 } \\
\text { Revised : 20-05-2019 } \\
\text { Accented } \cdot 16-06-2019\end{array}$ & $\begin{array}{l}\text { This article aimed to find out the development of teaching materials in the form } \\
\text { of modules by using Knisley's mathematical learning model on the subject of } \\
\text { decent, interesting, and effective linear transformation used in lectures in Linear }\end{array}$ \\
\hline Accepted :16-06-2019 & Algebra. The test subjects in this study were third semester students of Raden Intan \\
\hline Keywords: & $\begin{array}{l}\text { Lampung State Islamic University. This research method is Research and } \\
\text { Development }(\mathrm{R} \& \mathrm{D}) \text { that uses the ADDIE Model (Analysis, Design, }\end{array}$ \\
\hline $\begin{array}{l}\text { Knisley's Model; } \\
\text { Module; Linear } \\
\text { Transformation. }\end{array}$ & $\begin{array}{l}\text { Development, Implementation, and Evaluation). The results of the expert } \\
\text { assessment are feasible to use with an average score of } 3.00 \text { from material experts } \\
\text { and } 3.08 \text { from media experts. The response of students in small group trials is } \\
\text { interesting with an average score of } 2.92 \text {, whereas in the trial of a large group the } \\
\text { criteria are very interesting with an average score of } 3.27 \text {. The results of the n-gain } \\
\text { calculation at the pretest and posttest are } 0.70 \text { included in the high effectiveness } \\
\text { category. Therefore, it can be concluded that the linear transformation module } \\
\text { using Knisley's mathematics learning model is categorized as feasible, interesting, } \\
\text { and effective to be used in Linear Algebra lectures }\end{array}$ \\
\hline
\end{tabular}

\section{PENDAHULUAN}

Pendidikan mempunyai arti suatu proses kebutuhan yang harus dipenuhi dalam kehidupan dan telah disebutkan di dalam Al-qur'an bahwa proses pendidikan terjadi ketika Nabi Adam a.s. berdialog dengan Allah [1]. Pendidikan ini muncul disebabkan adanya motivasi pada Nabi Adam a.s. dan kehendak Allah sebagai pendidik yang mengajarkan langsung kepada Nabi Adam a.s. mengenai beberapa nama. Pada perkembangan teknologi zaman sekarang yang serba modern, maka pendidikan sangat penting. Tanpa pendidikan, seseorang bagaikan manusia yang berjalan di keadaan gelap tanpa penerangan sedikitpun, artinya pendidikan adalah proses untuk mendapatkan metode tertentu sehingga memperoleh pengetahuan, pemahaman, dan tingkah laku sesuai kebutuhan [2]. Fungsi pokok pendidikan adalah membantu peserta didik untuk menemukan dirinya sendiri atau untuk membentuk kepribadiannya [3]. Tujuan pendidikan dapat dicapai melalui proses belajar mengajar. Nirmala mengatakan bahwa belajar dan mengajar tidak dapat dipisahkan, dan akan berkolaborasi secara terpadu sehingga menjadi suatu kegiatan interaksi pada saat pembelajaran berlangsung [4]. Pembelajaran dapat juga disebut sebagai proses belajar untuk meningkatkan kemampuan pemahaman dengan mengoptimalkan penguasaan yang baik terhadap materi pembelajaran pada mata pelajaran tertentu, khususnya pada pelajaran matematika. Adapun mata pelajaran matematika adalah mata pelajaran yang paling dominan dipakai di semua pelajaran dan merupakan mata pelajaran paling penting yang dipelajari semenjak peserta didik belajar di tingkat dasar hingga perguruan tinggi. Matematika adalah pokok dari segala ilmu dan merupakan bahasa universal dari semua ilmu pengetahuan, karena materi yang diajarkan adalah ilmu pasti dan sangat berperan pada ilmu lainnya [5]. 
Tujuan dari pembelajaran yang sesungguhnya adalah apa yang dipelajari peserta didik bermanfaat untuk kehidupan sehari-harinya. Adapun anggapan dari pandangan learning as knowing yaitu matematika telah dipahami jika peserta didik telah mengetahui dan menghafal konsep-konsep dan hanya berpaku pada penghafalan rumus, sehingga pembelajaran yang berdasarkan pandangan ini hanya menghasilkan pengetahuan yang sekedar tahu saja [6]. Sebaliknya, pandangan learning as understanding beranggapan bahwa saat seorang peserta didik mengetahui konsep matematika, mereka merasa tidak cukup sebelum konsep tersebut terinternalisasi dan terhubung dengan pengetahuan peserta didik tersebut, sehingga pembelajaran yang berdasarkan pandangan ini menghasilkan peserta didik yang memahami konsep tersebut dan bahkan dapat mengaplikasikannya dalam kehidupan sehari-hari. Tujuan pandangan learning as understanding adalah belajar dengan pemahaman, sehingga ilmu yang dipelajari akan tetap diingat dan tidak sia-sia. Pembelajaran matematika akan berjalan efektif jika didukung oleh media pembelajaran. Media pembelajaran merupakan sumber belajar yang terdiri dari bahan-bahan materi yang dikumpulkan secara sengaja yang dapat memotivasi peserta didik dalam belajar. Bahan ajar adalah semua bentuk bahan yang digunakan untuk memudahkan pendidik dalam melaksanakan kegiatan belajar mengajar di dalam kelas. Bahan ajar yang sering dijumpai adalah bahan ajar berbentuk modul pembelajaran. Pembelajaran menggunakan modul dapat meningkatkan hasil belajar dan kemandirian peserta didik [7].

Aljabar Linear adalah mata kuliah yang mempelajari sistem persamaan linear, matriks, ruang vektor, termasuk transformasi linear. Peneliti telah menemukan kendala pada perkuliahan aljabar linear, khususnya pokok bahasan transformasi linear. Transformasi linear merupakan salah satu ilmu matematika yang perlu dikuasai dan dipelajari secara mendalam oleh mahasiswa. Berdasarkan pra penelitian yang dilakukan oleh peneliti di Universitas Islam Negeri Raden Intan Lampung menyatakan bahwa Aljabar Linear merupakan materi yang sulit dimengerti. Permasalahan tersebut berdasarkan hasil angket analisis kebutuhan mahasiswa yang dapat dilihat dari tabel 1.

Tabel 1.

Hasil Angket Mahasiswa

\begin{tabular}{clc}
\hline No. & \multicolumn{1}{c}{ Pernyataan } & Hasil \\
\hline 1 & Aljabar Linear itu sulit. & $83 \%$ \\
2 & $\begin{array}{l}\text { Bahan ajar belum menggunakan } \\
\text { model pembelajaran. }\end{array}$ & $60 \%$ \\
\hline \multicolumn{2}{c}{ Jumlah Responden } & 30 mahasiswa \\
\hline
\end{tabular}

Tabel 1 merupakan hasil angket analisis kebutuhan mahasiswa secara rinci yang disebutkan bahwa pada pengisian angket dilakukan sebanyak 30 orang responden dan skor yang diperoleh yaitu $83 \%$ atau setara dengan 25 mahasiswa menyatakan aljabar linear itu sulit, lalu 60\% atau setara dengan 18 mahasiswa mengharapkan bahan ajar yang menggunakan model pembelajaran. Pada kenyataannya, mahasiswa menilai bahan ajar yang digunakan sudah memenuhi tetapi masih membutuhkan bimbingan dari dosen pengampu dan tidak bisa mempelajari sendiri. Maka dari itu, mahasiswa memerlukan bahan ajar yang menggunakan model pembelajaran disertai pandangan learning as understanding agar pembelajaran menjadi bermakna dan memudahkan dalam memahami materi secara mandiri tanpa harus dijelaskan kembali oleh dosen.

Permasalahan tersebut sesuai dengan hasil wawancara oleh dosen pengampu mata kuliah Aljabar Linear Prodi Pendidikan Matematika Universitas Islam Negeri Raden Intan Lampung. Hasil wawancara diperoleh beberapa permasalahan yaitu sistem pembelajaran yang digunakan masih berpusat oleh dosen, lalu dilakukan diskusi dan latihan soal sehingga kemampuan mahasiswa masih relatif, ada yang aktif dan ada yang pasif dan menyebabkan hasil yang belum memuaskan. Oleh karena itu, mahasiswa mengalami kesulitan untuk memahami konsep suatu metode menyelesaikan transformasi linear dan kurangnya 
menguasai materi dasar dari aljabar. Hal tersebut menyebabkan masih banyak mahasiswa yang sering terjadi kekeliruan pada saat mengerjakan soal. Hal lain yang juga berpengaruh yaitu belum adanya modul yang terstruktur dan sistematis yang menjelaskan dari materi dasar sebagai acuan untuk materi baru yang membuat isi dari modul tersebut tersampaikan oleh mahasiswa itu sendiri tanpa perlu dijelaskan kembali oleh dosen. Permasalahan tersebut berdampak pada proses pembelajaran di kelas dimana mahasiswa hanya bergantung pada penjelasan dosen sehingga pembelajaran menjadi kurang bermakna.

Sazah satu cara untuk menangani permasalahan dari hasil pra penelitian yang telah dilakukan yaitu mengembangkan bahan ajar berbentuk modul. Hal tersebut juga mendapatkan respon positif oleh dosen pengampu mata kuliah Aljabar Linear tersebut, yang mengatakan sangat setujunya jika dikembangkan lagi bahan ajar yang selama ini telah mereka gunakan agar semakin banyak referensi pada pembelajaran aljabar linear khususnya materi transformasi linear.

Melihat permasalahan yang terjadi dari hasil pra penelitian yang dilakukan, perlu dikembangkan model pembelajaran yang menyenangkan, jauh lebih baik, memotivasi, dan bermanfaat. Salah satu model pembelajaran yang berdasarkan pandangan learning as understanding yaitu model pembelajaran matematika Knisley yang dikembangkan oleh Jeff Knisley. Model pembelajaran ini dikembangkan atas dasar gaya belajar Kolb yang terdapat empat gaya belajar ketika seseorang menemui dan akan mempelajari konsep baru[8]. Model ini sangat membantu mahasiswa dalam perkuliahan aljabar linear pada pokok bahasan transformasi linear. Model ini dapat mengacu mahasiswa belajar berdasarkan pandangan learning as understanding pada transformasi linear yang terbukti bahwa salah satu materi penting pada mata kuliah aljabar linear. Sehingga yang dapat dikembangkan yaitu digunakannya model pembelajaran matematika Knisley dan menghasilkan bahan ajar berbentuk media cetak yaitu berupa modul.

Uraian-uraian yang sudah dijelaskan sebelumnya, dapat diambil kesimpulan yaitu mahasiswa membutuhkan bahan ajar baru yang merupakan sebuah modul dengan ditambah model pembelajaran. Selain itu, mahasiswa harus mengubah gaya belajarnya ketika menemukan konsep baru agar pembelajarannya menjadi bermakna yaitu menggunakan pandangan learning as understanding. Model pembelajaran yang cocok dengan hal tersebut adalah model pembelajaran matematika Knisley. Tujuan penelitian ini adalah untuk mengetahui pengembangan bahan ajar Aljabar Linear dengan menggunakan model pembelajaran matematika Knisley.

\section{METODE}

Metode yang digunakan dalam penelitian ini adalah penelitian dan pengembangan (Research and Development). Research and Development merupakan proses pengembangan perangkat pendidikan yang dilakukan melalui serangkaian penelitian dengan menggunakan berbagai metode dalam suatu siklus yang melewati berbagai tahapan[9] [10]. Secara umum, metode penelitian diartikan sebagai cara ilmiah untuk mendapatkan data dengan tujuan tertentu[11] [12]. Tujuan dari penelitian ini adalah untuk mengetahui kelayakan dan respon mahasiswa terhadap modul transformasi linear dengan menggunakan model pembelajaran matematika Knisley. Penelitian ini menggunakan model ADDIE yang disesuaikan dengan kebutuhan penulis. Model ADDIE adalah termasuk salah satu model desain pembelajaran sistematik dan berpijak pada landasan teoritis desain pembelajaran [13]. Langkah-langkah model ADDIE terdiri dari lima tahap, yaitu Analysis, Design, Development, Implementation, dan Evaluation. Tahap analysis yang dilakukan adalah analisis bahan ajar dan analisis kebutuhan mahasiswa dengan menggunakan angket[14]. Tahap design yaitu penulis mulai merancang bahan ajar yang berbentuk modul lalu disesuaikan dengan hasil dari tahap analysis. Tahap development yaitu kegiatan menerjemahkan spesifikasi desain ke bentuk fisik, validasi produk ke validator, dan revisi produk. Tahap implementation yaitu uji coba produk ke mahasiswa. Tahap evaluation dilakukan untuk melihat permasalahan yang ada di setiap tahapan sebelumnya dan akan berhenti 
ketika produk dinyatakan valid oleh validator, mendapat respon yang menarik dari mahasiswa, dan produk dinyatakan efektif. Subjek penelitian dalam penelitian ini adalah mahasiswa pendidikan matematika Universitas Islam Negeri Raden Intan Lampung semester III angkatan tahun 2017.

Instrumen penelitian yang digunakan berupa pedoman wawancara sebagai acuan dalam melakukan wawancara kepada dosen pengampu yang disusun untuk mengetahui bahan ajar seperti apa yang sesuai dengan kebutuhan mahasiswa dan berfungsi untuk memberi masukan dalam pengembangan bahan ajar berupa modul transformasi linear dengan model pembelajaran matematika Knisley. Instrumen ahli materi dan ahli media yang digunakan berupa angket validasi untuk mengetahui kelayakan modul yang dikembangkan. Instrumen uji coba produk oleh mahasiswa berupa angket respon mahasiswa untuk mengetahui respon kemenarikan dari mahasiswa terhadap modul yang dikembangkan. Instrumen tes berupa pretest dan posttest untuk uji keefektifitasan terhadap modul yang dikembangkan.

Teknik analisis data dalam penelitian pengembangan ini yaitu menggunakan analisis kualitatif yang didapatkan dari hasil observasi dan wawancara, sedangkan analisis kuantitatif diperoleh melalui hasil validasi dan uji kelayakan, kemenarikan, dan keefektifan bahan ajar aljabar linear dengan model pembelajaran matematika Knisley. Cara menghitung skor penilaian total dicari dengan rumus sebagai berikut:

$$
\begin{aligned}
& \bar{x}=\frac{\sum_{i=1}^{n} x_{i}}{n} \\
& \text { dengan, } x_{i}=\frac{\text { jumlah skor }}{\text { skor maks }} \times 4
\end{aligned}
$$

Keterangan :

$\bar{x}=$ rata-rata akhir

$x_{i}=$ nilai uji operasional angket tiap responden

$n=$ banyaknya responden yang mengisi angket

\section{Analisis Data Validasi Ahli}

Analisis data validasi ahli diperoleh dari angket yang terkait dengan kelayakan isi dan sistematika materi dengan model pembelajaran matematika Knisley, kesesuaian pada desain modul, dan ketepatan bahasa. Berikut ini merupakan skor penilaian dari setiap pilihan jawaban pada tabel 2.

Tabel 2.

Skor Penilaian Validasi Ahli (dimodifikasi)

\begin{tabular}{cc}
\hline Skor & Pilihan Jawaban Kelayakan \\
\hline 4 & Sangat Setuju \\
3 & Setuju \\
2 & Kurang Setuju \\
1 & Tidak Setuju \\
\hline
\end{tabular}

Berikut ini adalah kriteria kelayakan analisis rata-rata pada tabel 3.

Tabel 3 .

Kriteria Validasi Ahli

\begin{tabular}{cc}
\hline Skor Kualitas & Kriteria Kelayakan \\
\hline $3,26<\bar{x} \leq 4,00$ & Sangat Layak Digunakan \\
$2,51<\bar{x} \leq 3,26$ & Layak Digunakan \\
$1,76<\bar{x} \leq 2,51$ & Kurang Layak Digunakan \\
$1,00<\bar{x} \leq 1,76$ & Tidak Layak Digunakan \\
\hline
\end{tabular}


Numerical: Jurnal Matematika dan Pendidikan Matematika, Vol. 3 No. 1 Juni 2019, 43-62

Ria Anggraeni Syafnuri, Netriwati, Dona Dinda Pratiwi

\section{Analisis Uji Coba Produk}

Angket respon mahasiswa memiliki jawaban sesuai dari konten pertanyaan. Masing-masing pilihan jawaban kemenarikan mempunyai skor berbeda mengenai kesesuaian produk bagi pengguna. Skor penilaiannya dapat dilihat pada tabel 4.

Tabel 4.

Skor Penilaian Uji Coba

\begin{tabular}{cc}
\hline Skor & Pilihan Jawaban Kemenarikan \\
\hline 4 & Sangat menarik \\
3 & Menarik \\
2 & Kurang menarik \\
1 & Sangat kurang menarik \\
\hline
\end{tabular}

Pengkonversian skor menjadi pernyataan penilaian sebagai berikut pada tabel 5 .

Tabel 5.

Kriteria untuk Uji Kemenarikan (dimodifikasi)

\begin{tabular}{cc}
\hline Skor Kualitas & $\begin{array}{c}\text { Pertanyaan Kualitas Aspek } \\
\text { Kemenarikan }\end{array}$ \\
\hline $3,26<\bar{x} \leq 4,00$ & Sangat Menarik \\
$2,51<\bar{x} \leq 3,26$ & Menarik \\
$1,76<\bar{x} \leq 2,51$ & Kurang Menarik \\
$1,00<\bar{x} \leq 1,76$ & Sangat Kurang Menarik \\
\hline
\end{tabular}

\section{Uji Efektivitas}

Tingkat keefektifan diperoleh dari hasil pretest dan posttest pada hasil belajar mahasiswa berupa gain score dengan perhitungan dengan rumus sebagai berikut:

$$
n-\text { gain }=\frac{(\text { skor posttest }- \text { skor pretest })}{(\text { skor maksimal }- \text { skor pretest })}
$$

Keterangan:

$n$ - gain: gain score

Kriteria tingkat keefektifan produk yang dibuat terdapat pada tabel 6 .

Tabel 6.

Kriteria Tingkat Keefektifan Produk

\begin{tabular}{cc}
\hline Kriteria Pencapaian Nilai & Tingkat Efektivitas \\
\hline$n-$ gain $\geq 0,7$ & Efektivitas tinggi \\
$0,3<n-$ gain $<0,7$ & Efektivitas sedang \\
$n-$ gain $\leq 0,3$ & Efektivitas rendah \\
\hline
\end{tabular}

\section{HASIL DAN PEMBAHASAN}

Produk yang dihasilkan pada penelitian dan pengembangan ini adalah bahan ajar berupa modul transformasi linear dengan menggunakan model pembelajaran matematika Knisley. Penelitian dan pengembangan menggunakan model ADDIE yang terdiri dari 5 tahap, yaitu analysis, design, development, implementation, dan evaluation. Hasil dari setiap tahap dapat dilihat sebagai berikut: 
Numerical: Jurnal Matematika dan Pendidikan Matematika, Vol. 3 No. 1 Juni 2019, 43-62 Ria Anggraeni Syafnuri, Netriwati, Dona Dinda Pratiwi

\section{Tahap Analisis (Analysis)}

Hasil analisis yang dilakukan penulis digunakan sebagai data awal untuk mengembangkan modul transformasi linear dengan model Knisley. Analisis kebutuhan diperoleh dari hasil wawancara dosen dan pengisian angket oleh mahasiswa. Analisis karakteristik mahasiswa berdasarkan pengisian angket oleh mahasiswa. Kesimpulan dari hasil wawancara dosen mata kuliah Aljabar Linear dan pengisian angket oleh mahasiswa, yaitu sebagai berikut:

1. Mahasiswa masih menggunakan pandangan learning as knowing saat pembelajaran berlangsung.

2. Mahasiswa menganggap Aljabar Linear itu sulit.

3. Mahasiswa masih belajar dengan berpusat pada dosen sehingga masih ada yang merasa kesulitan ketika menghadapi latihan soal.

4. Belum adanya modul Aljabar Linear yang menggunakan model pembelajaran terstruktur yang dapat dipahami oleh mahasiswa.

Berdasarkan dari hasil analisis kebutuhan dan karakteristik mahasiswa, maka penulis akan mengembangkan bahan ajar berupa modul transformasi linear dengan model pembelajaran matematika Knisley. Modul tersebut mempunyai tujuan supaya dapat mengatasi permasalahan yang ada dan mahasiswa dapat belajar lebih mudah, karena materi yang disampaikan dapat menimbulkan rasa ingin tahu serta semangat dalam proses pembelajaran.

\section{Tahap Perancangan (Design)}

a. Penyusunan Desain Modul

Pembuatan modul pada bagian isi menggunakan Microsoft Office Word 2007, ukuran kertas yang digunakan adalah B5, spasi 1,5; jenis huruf yang digunakan pada setiap judul bab adalah Beli MT, pada judul subbab adalah Cambria, pada bagian isi adalah Times New Roman. Sedangkan pembuatan cover depan dan belakang menggunakan Corel Draw X4. Penyusunan desain modul dimulai dengan menyusun kerangka modul yang terdiri dari bagian awal, bagian isi, dan bagian penutup.

b. Perancangan Instrumen Penilaian

Instrumen penelitian pengembangan produk ini adalah angket yang disusun untuk mengevaluasi modul yang telah dibuat. Instrumen yang disusun yaitu angket validasi ahli materi dan media. Angket yang sudah disusun diberikan kepada para ahli pada saat mereview modul sebelum dilakukan uji coba di lapangan. Setelah modul selesai divalidasi oleh para ahli, selanjutnya dilakukan uji coba kepada mahasiswa dengan angket respon terhadap modul. Instrumen penilaian kualitas modul yang telah dikembangkan yaitu berupa angket check list untuk ahli materi, ahli media, dan mahasiswa.

\section{Tahap Pengembangan (Development)}

Pada tahap pengembangan, modul mulai dibuat berdasarkan rancangan pada tahap design. Kegiatan yang dilakukan pada tahap pengembangan, yaitu:

a. Pembuatan Draft Modul

Draft modul yang disesuaikan dengan model Knisley dikembangkan menjadi modul dengan rancangan sebagai berikut:

1) Cover Depan

Cover depan terdiri dari judul modul, gambar, dan nama penyusun. Pembuatan cover depan menggunakan Corel Draw X4. Cover depan pada pengembangan modul ini terdapat notasi $T: V \rightarrow W$ di dalam papan tulis, selain itu ada diagram panah, kalkulator, dan gambar matriks. Gambar-gambar tersebut berkaitan dengan pembelajaran transformasi linear. Background sampul berupa angka-angka yang merupakan unsur kematematikaan. Cover depan dikemas 
Numerical: Jurnal Matematika dan Pendidikan Matematika, Vol. 3 No. 1 Juni 2019, 43-62

Ria Anggraeni Syafnuri, Netriwati, Dona Dinda Pratiwi

dengan gambar dan warna yang padu sehingga menimbulkan kesan elegan, simple, dan menarik bagi pembacanya terkhusus mahasiswa.

2) Cover Bagian Dalam

Cover bagian dalam merupakan tim dari pembuatan modul ini. Cover bagian dalam terdiri dari judul modul, nama penulis, dosen pembimbing, tim validator, desain cover, dan desain layout.

3) Kata Pengantar

Kata pengantar mempunyai fungsi untuk mengarahkan pembaca kepada isi yang terdapat di dalam modul. Kata pengantar pada modul ini berisi ucapan syukur kepada Allah SWT dan menjelaskan tujuan dibuatnya modul transformasi linear ini.

4) Daftar Isi

Daftar isi memuat petunjuk halaman cover, cover dalam, kata pengantar, daftar isi, pendahuluan, peta konsep, bab allegorisasi, bab integrasi, bab analisis, bab sintesis, glosarium, dan daftar pustaka.

5) Pendahuluan

Bagian pendahuluan menjelaskan langkah model Knisley pada modul dan sejarah singkat Aljabar Linear. Bagian pendahuluan berguna untuk menuntun pembaca dalam penggunaan modul transformasi linear.

6) Peta Konsep

Peta konsep merupakan suatu skema atau rangkuman dari materi yang dipelajari. Peta konsep materi transformasi linear terdiri dari syarat transformasi linear, terdapat sifat-sifat transformasi linear, ruang null (kerne), dan jangkauan (range).

7) Bagian Isi

Pada bagian isi terdapat materi dari transformasi linear yang berdasarkan langkah model Knisley, yaitu tahap allegorisasi (materi dasar), integrasi, analisis (materi inti), dan sintesis (latihan soal). Tampilan bagian isi dapat dilihat pada gambar-gambar berikut.

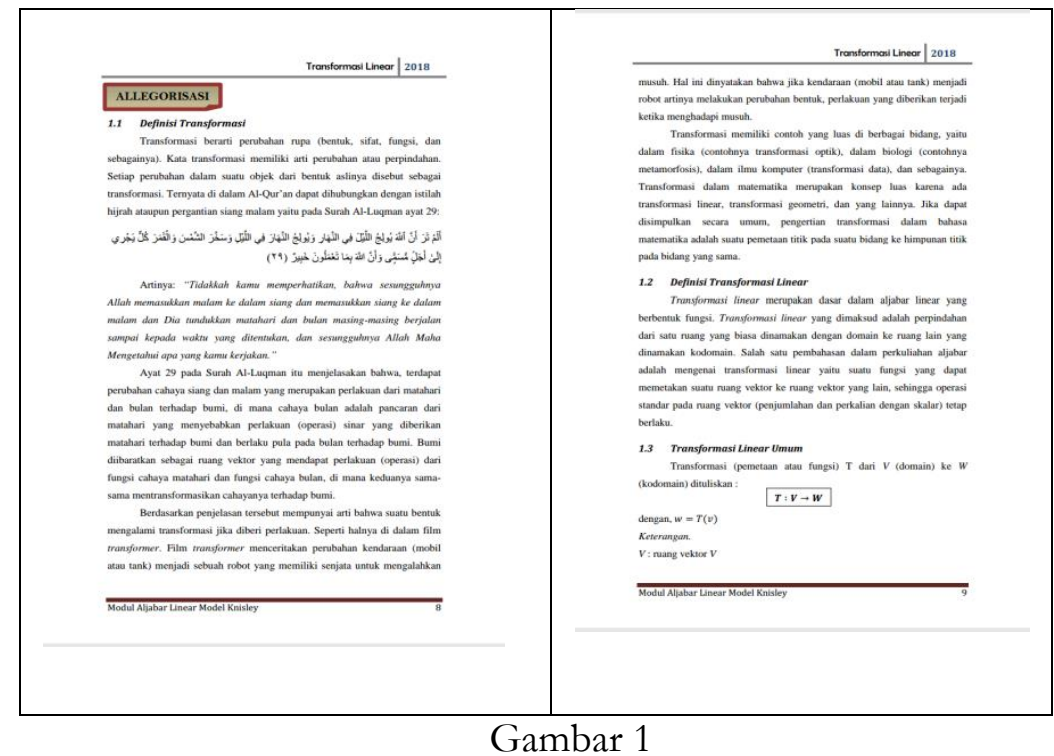

Tampilan Awal Tahap Materi I (Allegorisasi) 
Numerical: Jurnal Matematika dan Pendidikan Matematika, Vol. 3 No. 1 Juni 2019, 43-62

Ria Anggraeni Syafnuri, Netriwati, Dona Dinda Pratiwi

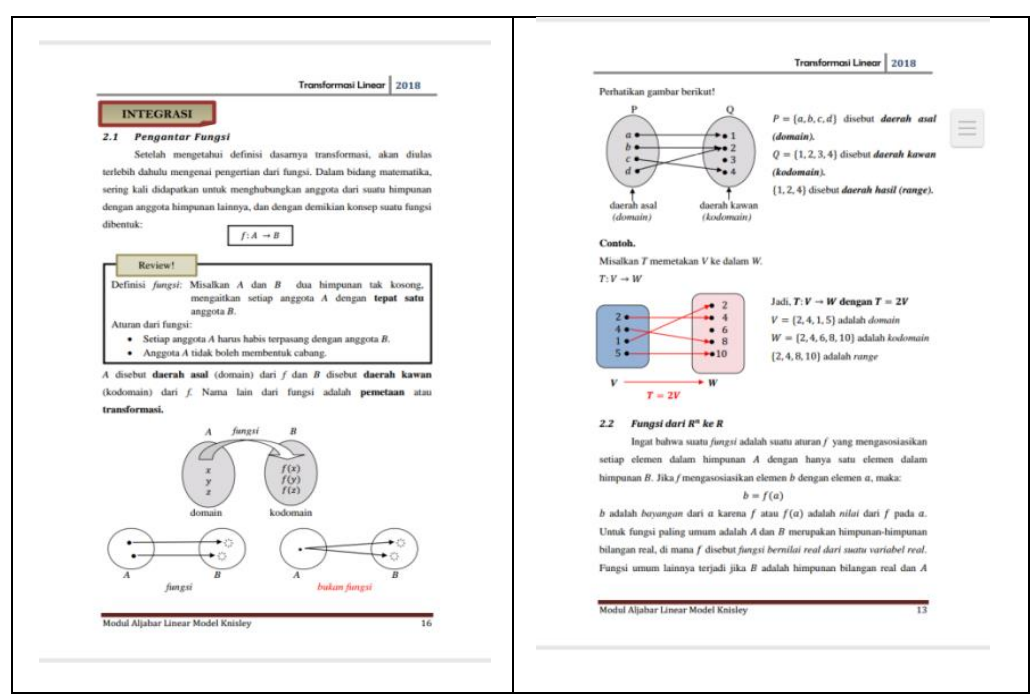

Gambar 2

Tampilan Awal Tahap Materi II (Integrasi)

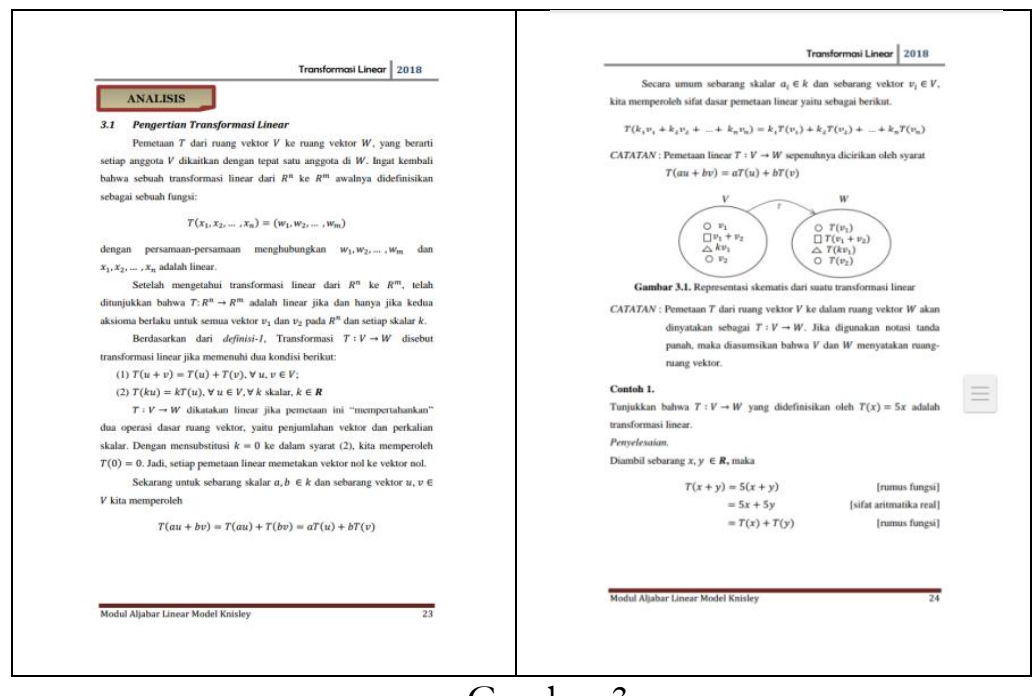

Gambar 3

Tampilan Awal Tahap Materi III (Analisis)

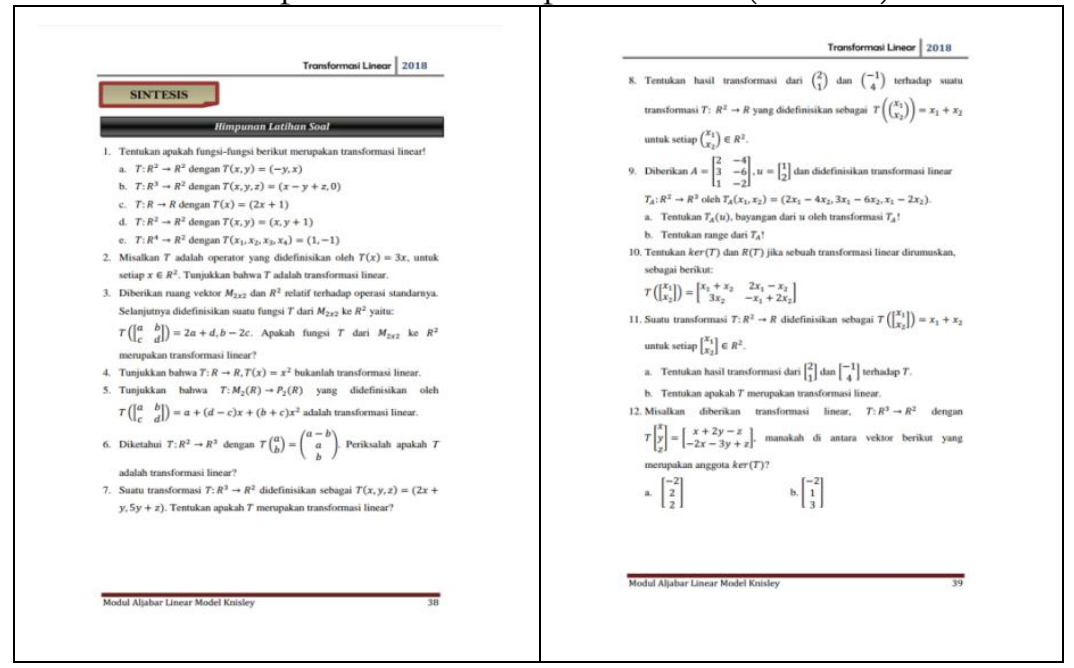

Gambar 4

Tampilan Awal Tahap Latihan Soal (Sintesis) 
Numerical: Jurnal Matematika dan Pendidikan Matematika, Vol. 3 No. 1 Juni 2019, 43-62

Ria Anggraeni Syafnuri, Netriwati, Dona Dinda Pratiwi

8) Glosarium

Glosarium merupakan pengertian dari kata-kata istilah yang terdapat di dalam pembahasan materi. Glosarium disusun berdasarkan huruf abjad, diambil kata-kata istilah dalam pembahasan materi dan memiliki arti tersendiri dalam ilmu matematika.

9) Daftar Pustaka

Daftar pustaka dibuat sebagai pelengkap modul supaya pembaca dapat mengetahui sumber aslinya. Daftar pustaka memuat sumber referensi yang digunakan dalam penyusunan modul transformasi linear dengan model Knisley. Pembuatan modul transformasi linear model Knisley mengacu pada sumber bahan ajar Aljabar Linear tingkat universitas untuk mencari sumber yang berkaitan dengan materi transformasi, peneliti juga mengambil beberapa teori dasar, serta materi dasar di kelas VIII SMP.

10) Cover Belakang

Cover belakang berisi profil penulis. Profil penulis dibuat dengan tujuan agar pembaca dapat mengetahui biodata penulis modul aljabar linear dengan model Knisley pada materi transformasi linear.

b. Validasi Produk

1) Hasil Validasi Ahli Materi

Validasi ahli materi mempunyai tujuan untuk menguji kelayakan isi, sistematika materi, dan ketepatan bahasa. Hasil validasi dari ahli materi tahap 1 dapat dilihat pada tabel 7.

Tabel 7.

Hasil Validasi Ahli Materi Tahap 1

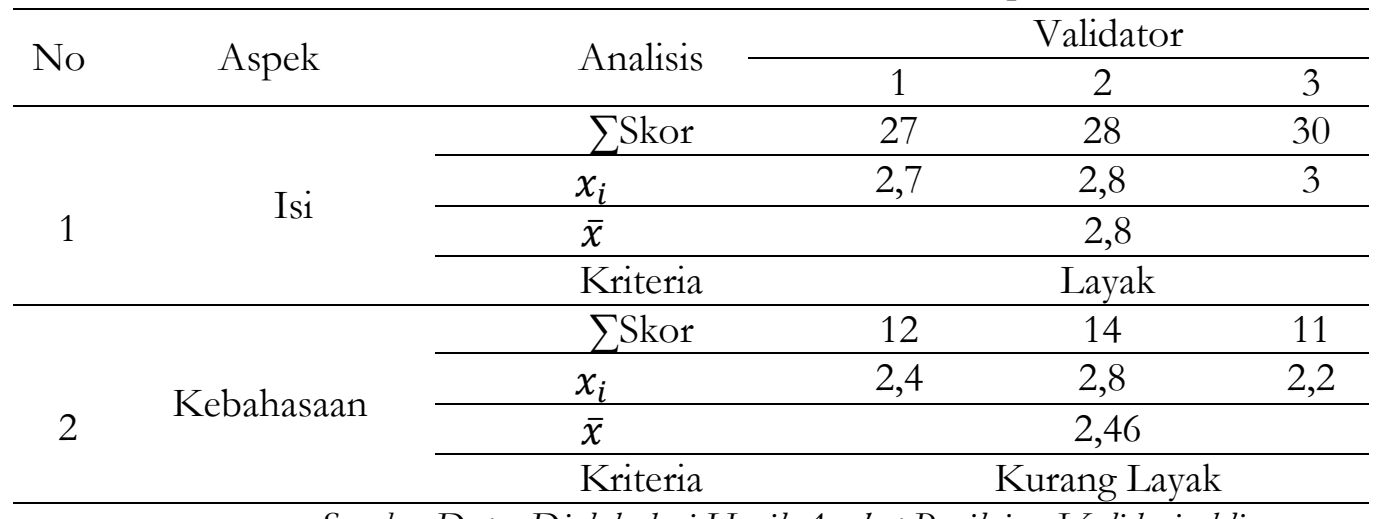

Sumber Data: Diolah dari Hasil Angket Penilaian Validasi abli

Berdasarkan hasil validasi ahli materi tahap 1 pada tabel 7 dapat diketahui bahwa validasi ahli materi memperoleh nilai sebagai berikut: pada aspek isi diperoleh nilai rata-rata sebesar 2,8 dengan kriteria "layak", pada aspek kebahasaan diperoleh nilai rata-rata sebesar 2,46 dengan kriteria "kurang layak". Selain dalam bentuk tabel hasil validasi ahli materi tahap 1 disajikan juga data dalam bentuk grafik untuk melihat penilaian dari masing-masing validator. 
Numerical: Jurnal Matematika dan Pendidikan Matematika, Vol. 3 No. 1 Juni 2019, 43-62

Ria Anggraeni Syafnuri, Netriwati, Dona Dinda Pratiwi

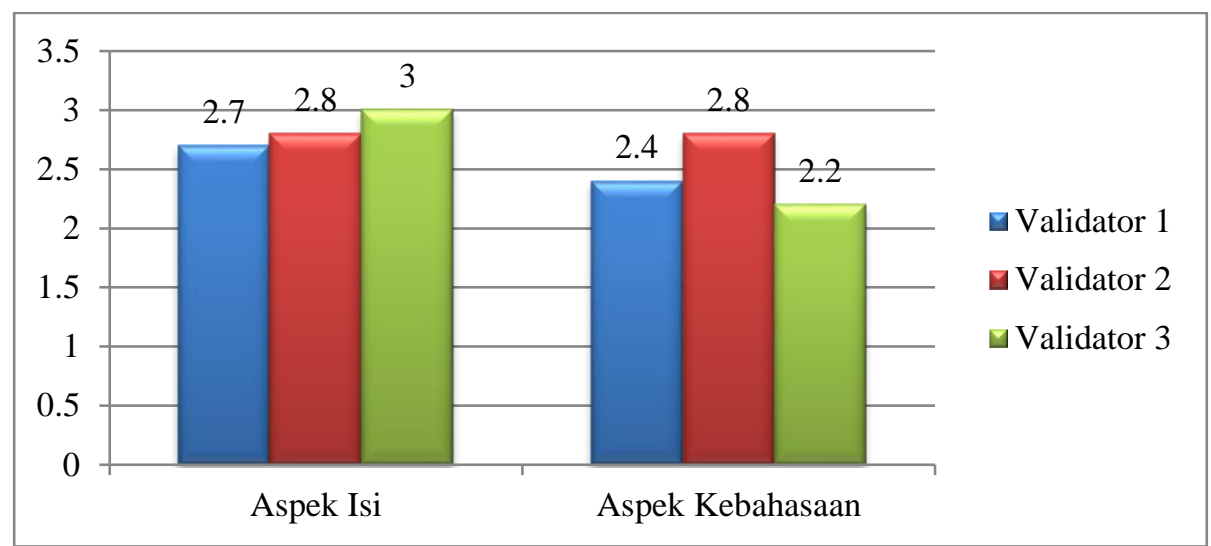

Gambar 5. Grafik Hasil Validasi Ahli Materi Tahap 1

Setelah selesai dilakukan validasi pada tahap 1 dan modul yang dibuat telah direvisi, maka selanjutnya akan dilakukan validasi ahli materi tahap 2. Validasi ahli materi tahap 2 mempunyai tujuan untuk melihat kriteria hasil modul yang sudah direvisi atau diperbaiki oleh peneliti. Hasil validasi dari ahli materi tahap 2 dapat dilihat pada tabel 8 .

Tabel 8.

Hasil Validasi Ahli Materi Tahap 2

\begin{tabular}{|c|c|c|c|c|c|}
\hline \multirow{2}{*}{ No } & \multirow{2}{*}{ Aspek } & \multirow{2}{*}{ Analisis } & \multicolumn{3}{|c|}{ Validator } \\
\hline & & & 1 & 2 & 3 \\
\hline \multirow{4}{*}{1} & \multirow{4}{*}{ Isi } & $\sum$ Skor & 30 & 30 & 33 \\
\hline & & $x_{i}$ & 3,0 & 3,0 & 3,3 \\
\hline & & $\bar{x}$ & & 3,1 & \\
\hline & & Kriteria & & ayak & \\
\hline \multirow{4}{*}{2} & \multirow{4}{*}{ Kebahasaan } & ESkor & 15 & 14 & 16 \\
\hline & & $x_{i}$ & 3,0 & 2,8 & 3,2 \\
\hline & & $\bar{x}$ & & 3,0 & \\
\hline & & Kriteria & & ayak & \\
\hline
\end{tabular}

Sumber Data: Diolah dari Hasil Angket Penilaian Validasi abli

Berdasarkan hasil validasi ahli materi tahap 2 pada tabel 8 dapat diketahui bahwa validasi ahli materi memperoleh nilai sebagai berikut: pada aspek isi diperoleh nilai ratarata sebesar 3,1 dengan kriteria "layak", pada aspek kebahasaan diperoleh nilai rata-rata sebesar 3,0 dengan kriteria "layak". Selain dalam bentuk tabel hasil validasi ahli materi tahap 2 disajikan juga data dalam bentuk grafik untuk melihat penilaian dari masingmasing validator. 
Numerical: Jurnal Matematika dan Pendidikan Matematika, Vol. 3 No. 1 Juni 2019, 43-62

Ria Anggraeni Syafnuri, Netriwati, Dona Dinda Pratiwi

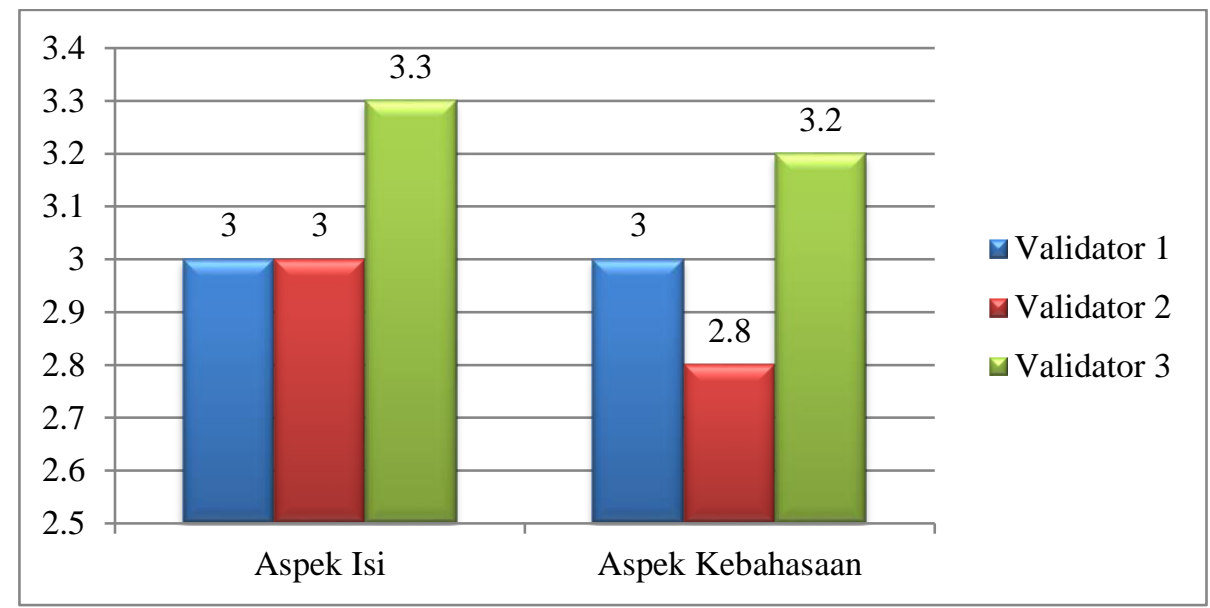

Gambar 6. Grafik Hasil Validasi Ahli Materi Tahap 2

Berdasarkan gambar 6 grafik hasil validasi ahli materi tahap 2 terlihat bahwa pada aspek isi mengalami peningkatan yang cukup baik, begitupun pada aspek kebahasaan. Nilai rata-rata sudah bernilai valid, maka materi pada modul transformasi linear dengan model Knisley sudah layak dan tidak perlu dilakukan perbaikan kembali.Hasil validasi ahli materi tahap 1 mengalami peningkatan pada tahap ke 2 . Nilai pada aspek isi pada tahap 1 diperoleh rata-rata skor sebesar 2,8 dengan kriteria "layak" dan pada tahap 2 rata-rata skor sebesar 3,1 dengan kriteria "layak" sedangkan pada aspek kebahasaan pada tahap 1 diperoleh rata-rata skor sebesar 2,46 dengan kriteria "kurang layak" dan pada tahap 2 ratarata skor sebesar 3,0 dengan kriteria "layak". Perbandingan hasil validasi ahli materi tahap 1 dan tahap 2 dapat dilihat pada gambar 7 berikut.

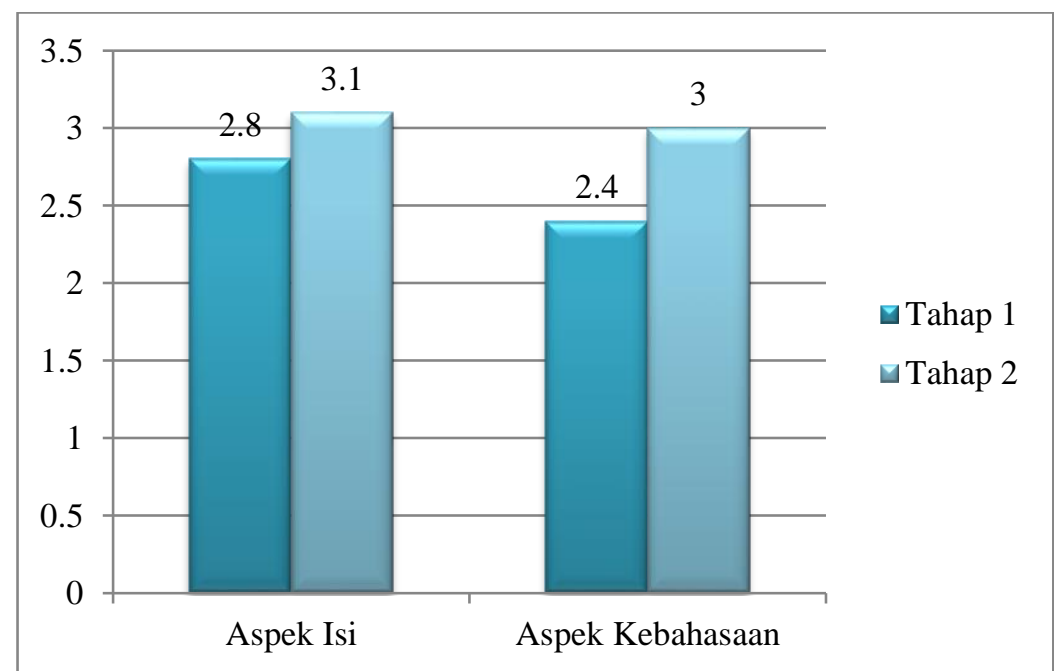

Gambar 7. Perbandingan Hasil Validasi Ahli Materi Tahap 1 dan 2

Berdasarkan gambar 1 grafik perbandingan hasil validasi tahap 1 dan tahap 2 terlihat bahwa terdapat peningkatan pada aspek isi dan aspek kebahasaan. Maka dari itu, dari kedua aspek tersebut dinyatakan valid dan modul transformasi linear dengan model Knisley sudah layak digunakan. 
Numerical: Jurnal Matematika dan Pendidikan Matematika, Vol. 3 No. 1 Juni 2019, 43-62

Ria Anggraeni Syafnuri, Netriwati, Dona Dinda Pratiwi

2) Hasil Validasi Ahli Media

Validasi ahli media mempunyai tujuan untuk menguji kegrafikan atau kesesuaian modul dan penyajian pada modul transformasi linear dengan model Knisley. Hasil validasi dari ahli media dapat dilihat pada tabel 9.

Tabel 9.

Hasil Validasi Ahli Media

\begin{tabular}{|c|c|c|c|}
\hline \multirow{2}{*}{ Aspek } & \multirow{2}{*}{ Analisis } & \multicolumn{2}{|c|}{ Tahap } \\
\hline & & 1 & 2 \\
\hline \multirow{4}{*}{$\begin{array}{l}\text { Kelayakan } \\
\text { Kegrafikan }\end{array}$} & $\sum$ Skor & 63 & 91 \\
\hline & Nilai Max & 100 & 100 \\
\hline & $x_{i}$ & 2,52 & 3,64 \\
\hline & Kriteria & Layak & Sangat Layak \\
\hline \multicolumn{2}{|c|}{ Rata-rata total } & \multicolumn{2}{|c|}{3,08} \\
\hline \multicolumn{2}{|c|}{ Keterangan Akhir } & \multicolumn{2}{|c|}{ Layak Digunakan } \\
\hline
\end{tabular}

Berdasarkan tabel 9 yaitu hasil validasi ahli media, diperoleh hasil penilaian dari 1 validator dengan proses 2 tahap validasi. Hasil validasi penilaian ahli media terdiri dari satu aspek yaitu aspek kelayakan kegrafikan. Hasil validasi pada tahap 1 yaitu "layak" dengan berbagai masukan dan saran oleh ahli media, sehingga pada saat validasi penilaian tahap 2 yaitu diperoleh nilai rata-rata "sangat layak".

Selain dalam bentuk tabel, hasil validasi ahli media disajikan juga data dalam bentuk grafik. Aspek kelayakan kegrafikan mengalami peningkatan yang sangat baik dan termasuk ke dalam kriteria "layak digunakan". Maka dari itu modul transformasi linear sudah layak digunakan dan tidak perlu dilakukan revisi kembali. Perbandingan hasil validasi ahli media tahap 1 dan tahap 2 dapat dilihat pada gambar 8 berikut.

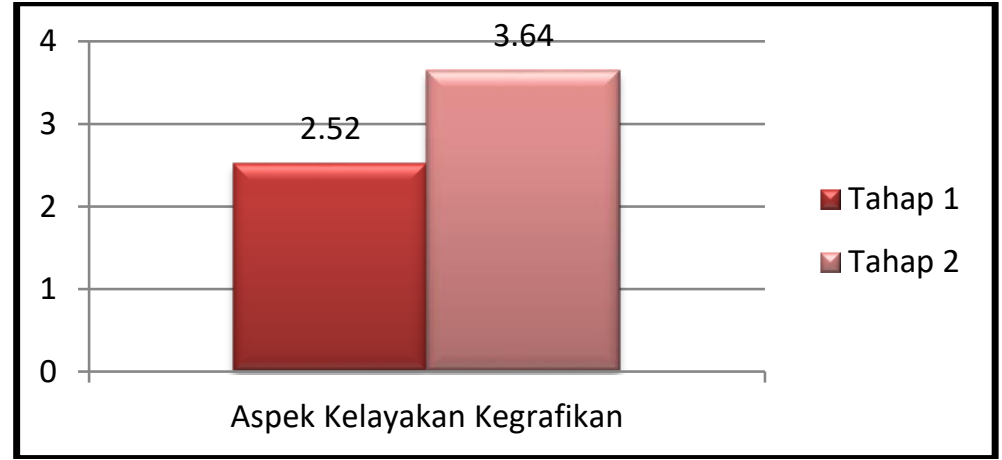

Gambar 8.

Perbandingan Hasil Validasi Ahli Media Tahap 1 dan 2

Aspek kelayakan kegrafikan mengalami peningkatan yang sangat baik dan termasuk ke dalam kriteria "layak digunakan". Maka dari itu modul transformasi linear sudah layak digunakan dan tidak perlu dilakukan revisi kembali.

c. Revisi Produk

Adapun saran perbaikan dari validator adalah sebagai berikut.

1) Saran Perbaikan Ahli Materi

a) Perbaiki kembali keruntutan materi supaya lebih jelas.

b) Bagian definisi dan teorema diberi nomor.

c) Sistematika penulisan diperbaiki.

d) Sejarah aljabar linear di pendahuluan lebih diperluas. 
Numerical: Jurnal Matematika dan Pendidikan Matematika, Vol. 3 No. 1 Juni 2019, 43-62

Ria Anggraeni Syafnuri, Netriwati, Dona Dinda Pratiwi

e) Tambahkan keterangan rumus.

f) Tata bahasa di kata pengantar dan pendahuluan diperbaiki kembali.

Hasil validasi yang terdapat saran revisi oleh ahli materi akan digunakan untuk perbaikan modul transformasi linear dengan model Knisley. Hasil perbaikan menurut saran dari ahli materi disajikan pada beberapa gambar di bawah ini.

\begin{tabular}{|c|c|c|}
\hline Trantormasi Lnear | 2018 & Transformasi Linear | 2018 & \\
\hline 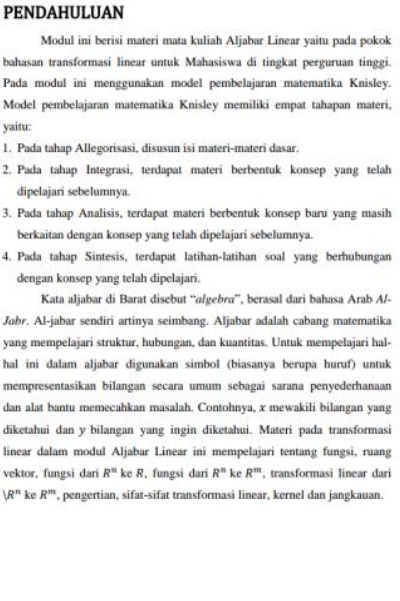 & 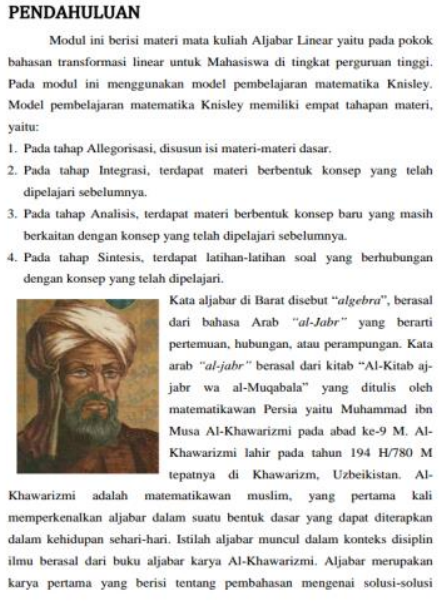 & $\equiv$ \\
\hline ModuluAlaharar Linear Model Knilisey & Modul Aliabar Linear Model Knisley & \\
\hline Sebelum revisi & Sesudah revisi & \\
\hline
\end{tabular}

Gambar 9.

Perbaikan Pada Pendahuluan

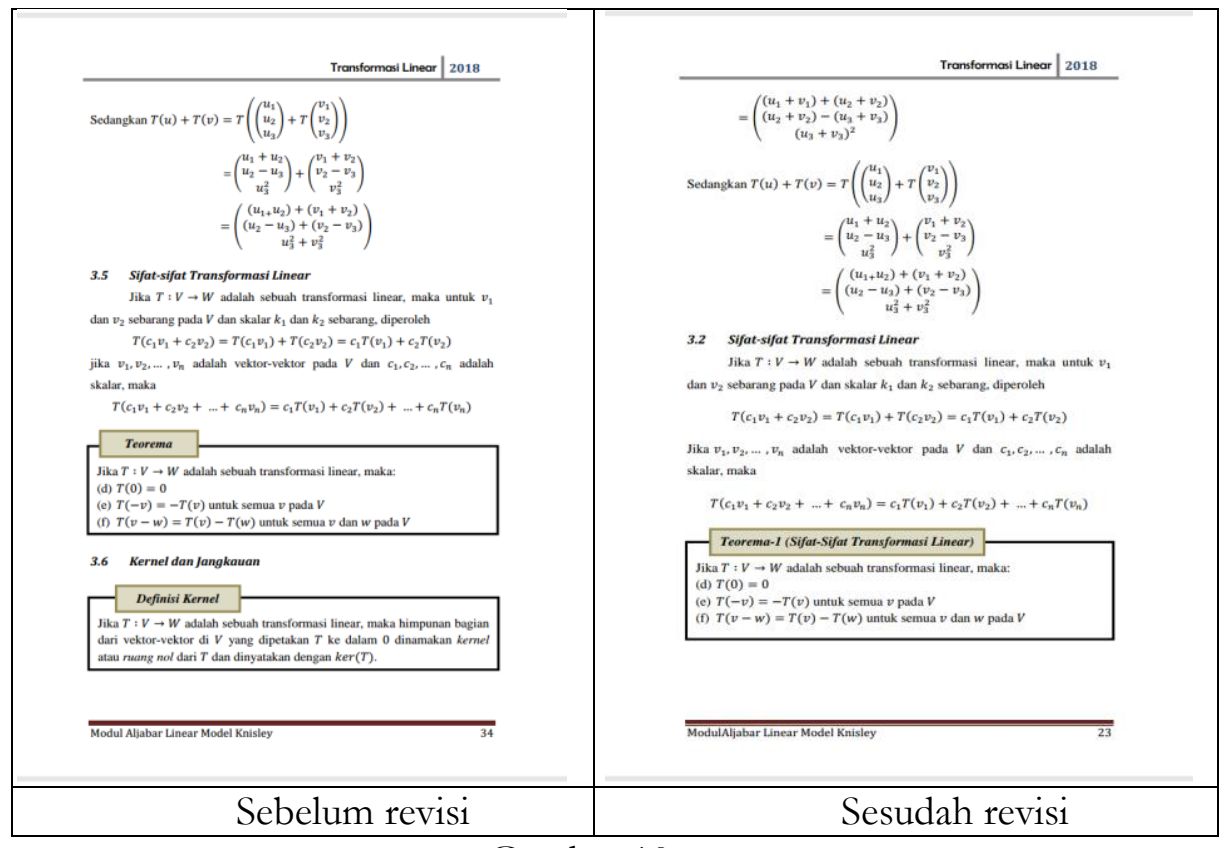

Gambar 10

Penambahan Nomor Pada Teorema dan Definisi 
Numerical: Jurnal Matematika dan Pendidikan Matematika, Vol. 3 No. 1 Juni 2019, 43-62

Ria Anggraeni Syafnuri, Netriwati, Dona Dinda Pratiwi

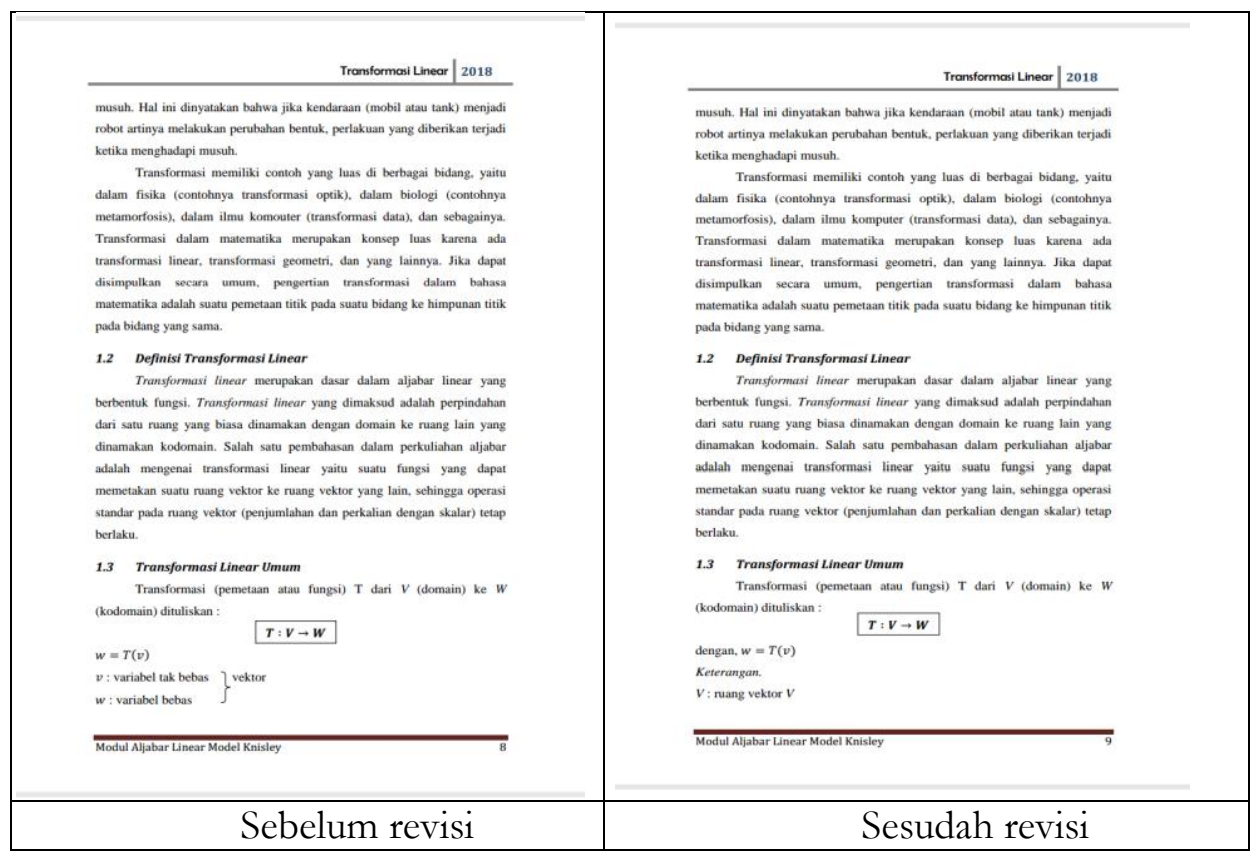

Gambar 11

Penambahan Keterangan Pada Rumus

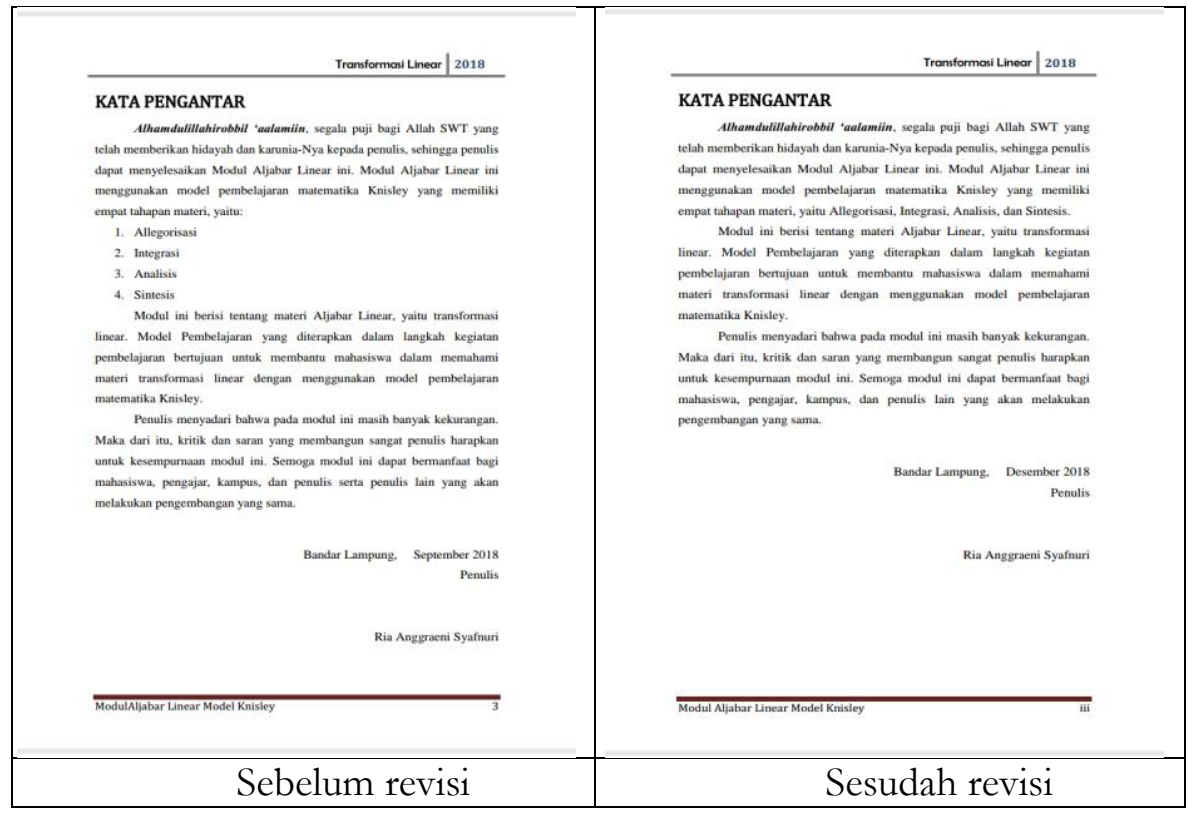

Gambar 12.

Perbaikan Penulisan Pada Isi Kata Pengantar

2) Saran Perbaikan Ahli Media

a) Perbaiki cover depan dengan corel draw

b) Tambahkan riwayat hidup penulis di sampul belakang

c) Perbaiki kembali kesalahan penulisan (tipo)

Hasil perbaikan menurut saran dari ahli media disajikan pada gambar-gambar berikut. 
Numerical: Jurnal Matematika dan Pendidikan Matematika, Vol. 3 No. 1 Juni 2019, 43-62

Ria Anggraeni Syafnuri, Netriwati, Dona Dinda Pratiwi

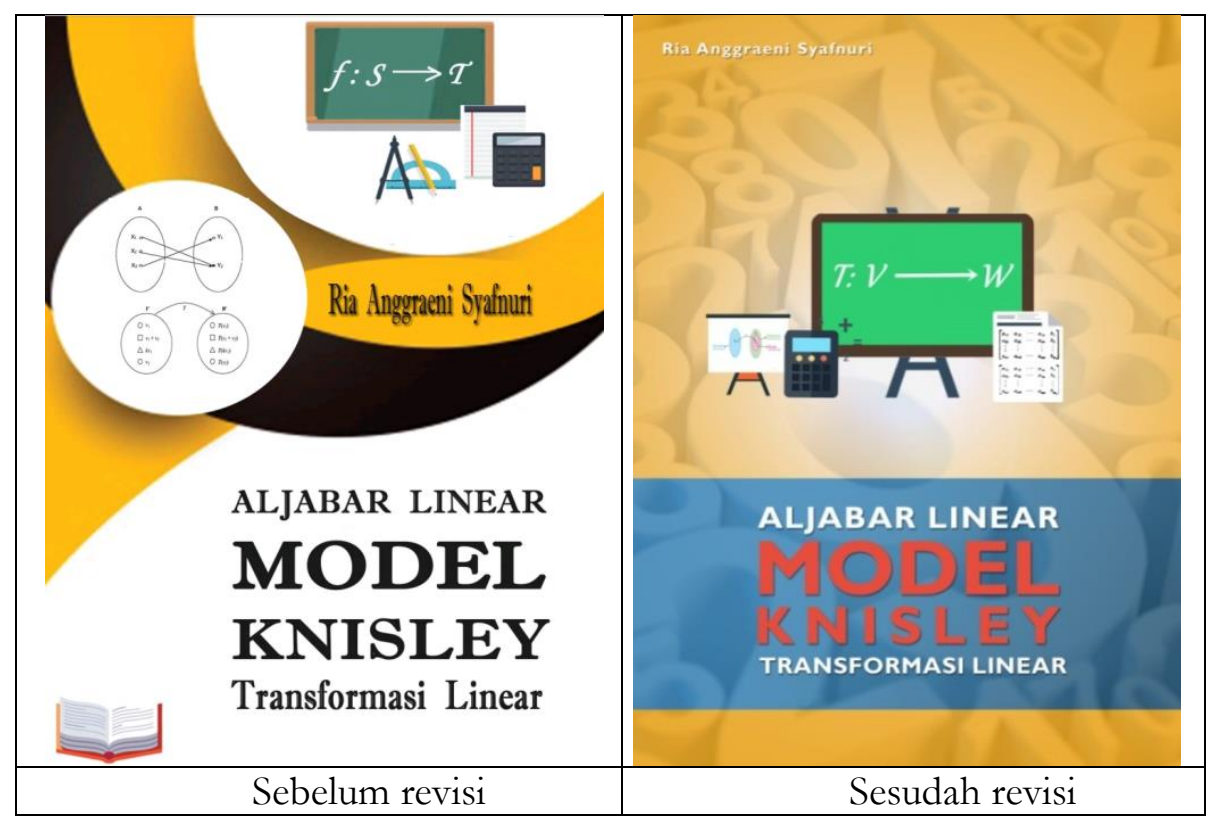

Gambar 13.

Perbaikan Pada Cover Depan

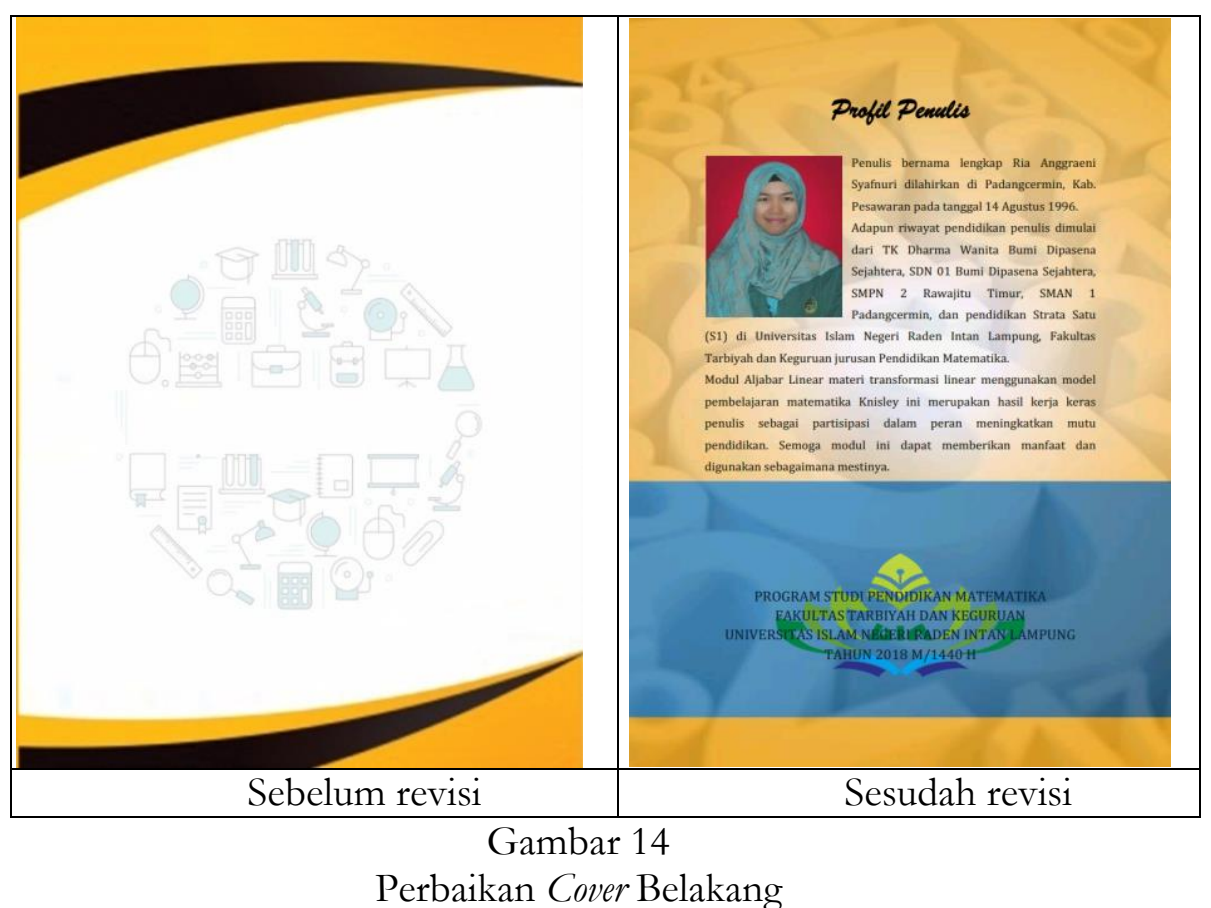

\section{Tahap Implementasi (Implementation)}

a. Uji Coba Kelompok Kecil

Uji coba kelompok kecil menggunakan teknik purposive sampling yaitu dengan cara memilih 2 mahasiswa dengan kemampuan tinggi (pintar), 2 mahasiswa dengan kemampuan cukup (cukup pintar), dan 2 mahasiswa dengan kemampuan rendah (kurang pintar) dipilih berdasarkan data nilai mahasiswa oleh Dosen pengampu. Hasil uji coba dapat dilihat pada tabel 10. 
Numerical: Jurnal Matematika dan Pendidikan Matematika, Vol. 3 No. 1 Juni 2019, 43-62

Ria Anggraeni Syafnuri, Netriwati, Dona Dinda Pratiwi

Tabel 10.

Hasil Uji Coba Kelompok Kecil

\begin{tabular}{|c|c|c|c|}
\hline No. & Nama Responden & Jumlah Skor & Skor Kemenarikan \\
\hline 1 & Responden 1 & 52 & 3,46 \\
\hline 2 & Responden 2 & 42 & 2,80 \\
\hline 3 & Responden 3 & 43 & 2,86 \\
\hline 4 & Responden 4 & 43 & 2,86 \\
\hline 5 & Responden 5 & 52 & 2,80 \\
\hline \multirow[t]{2}{*}{6} & Responden 6 & 51 & 2,73 \\
\hline & Jumlah & 263 & $\bar{x}=2,92$ \\
\hline
\end{tabular}

Berdasarkan hasil angket uji coba kelompok kecil pada tabel 4.6 diperoleh rata-rata 2,92 dengan kriteria uji kemenarikan yang dicapai yaitu "menarik".

b. Uji Coba Kelompok Besar

Responden pada uji coba kelompok besar adalah mahasiswa Prodi Pendidikan Matematika Universitas Islam Negeri Raden Intan Lampung berjumlah 18 orang dengan cara memberi angket untuk mengetahui respon mahasiswa terhadap modul yang dikembangkan. Hasil uji coba kelompok besar dilihat pada tabel 11.

Tabel 11.

Hasil Uji Coba Kelompok Besar

\begin{tabular}{|c|c|c|c|}
\hline No. & Nama Responden & Jumlah Skor & Skor Kemenarikan \\
\hline 1 & Responden 1 & 45 & 3,00 \\
\hline 2 & Responden 2 & 51 & 3,40 \\
\hline 3 & Responden 3 & 44 & 2,93 \\
\hline 4 & Responden 4 & 45 & 3,00 \\
\hline 5 & Responden 5 & 50 & 3,33 \\
\hline 6 & Responden 6 & 48 & 3,20 \\
\hline 7 & Responden 7 & 51 & 3,40 \\
\hline 8 & Responden 8 & 50 & 3,33 \\
\hline 9 & Responden 9 & 49 & 3,26 \\
\hline 10 & Responden 10 & 53 & 3,53 \\
\hline 11 & Responden 11 & 49 & 3,26 \\
\hline 12 & Responden 12 & 50 & 3,33 \\
\hline 13 & Responden 13 & 52 & 3,46 \\
\hline 14 & Responden 14 & 45 & 3,00 \\
\hline 15 & Responden 15 & 49 & 3,26 \\
\hline 16 & Responden 16 & 51 & 3,40 \\
\hline 17 & Responden 17 & 53 & 3,53 \\
\hline \multirow[t]{2}{*}{18} & Responden 18 & 50 & 3,33 \\
\hline & Jumlah & 885 & $\bar{x}=3,27$ \\
\hline
\end{tabular}

Berdasarkan hasil angket uji coba kelompok besar pada tabel 4.7 diperoleh rata-rata 3,27 dengan kriteria uji kemenarikan yang dicapai yaitu "sangat menarik".

c. Uji Efektivitas

Pada uji efektivitas ini, peneliti melakukan pertemuan perkuliahan lalu memberi soal pretest dan posttest pada mahasiswa dengan tujuan untuk mengetahui produk yang telah dibuat telah 
Numerical: Jurnal Matematika dan Pendidikan Matematika, Vol. 3 No. 1 Juni 2019, 43-62

Ria Anggraeni Syafnuri, Netriwati, Dona Dinda Pratiwi

efektif untuk diterapkan dalam perkuliahan Aljabar Linear. Hasil perhitungan pretest dan posttest dilihat pada tabel 12 .

Tabel 12.

Hasil Perhitungan Pretest dan Posttest

\begin{tabular}{lccccc}
\hline & $n$ & Skor Ideal & $\begin{array}{c}\text { Skor } \\
\text { Minimum }\end{array}$ & $\begin{array}{c}\text { Skor } \\
\text { Maksimum }\end{array}$ & $\bar{x}$ \\
\hline Pretest & 25 & 100 & 35 & 60 & 43,40 \\
Posttest & 25 & 100 & 73 & 90 & 83,12 \\
\hline
\end{tabular}

Berdasarkan data yang diperoleh pada tabel 9 perhitungan pretest dan posttest dapat dilihat perolehan skor minimum, skor maksimum, dan $\bar{x}$. Hasil skor minimum dari pretest adalah 35 dan posttest adalah 73. Hasil skor maksimum dari pretest adalah 60 dan posttest adalah 90 . Nilai $\bar{x}$ pada pretest adalah 43,40 dan posttest adalah 83,12. Rekapitulasi nilai n-gain dapat dilihat pada tabel 13.

Tabel 13.

Rekapitulasi Nilai $n$-gain

\begin{tabular}{cccccc}
\hline \multirow{2}{*}{ Kelas } & \multirow{n}{*}{$n$} & \multicolumn{4}{c}{ Nilai } \\
\cline { 3 - 6 } & & $\begin{array}{c}\text { Skor } \\
\text { Ideal }\end{array}$ & $\begin{array}{c}\text { Skor } \\
\text { Minimum }\end{array}$ & $\begin{array}{c}\text { Skor } \\
\text { Maksimum }\end{array}$ & $\begin{array}{c}\text { Rata-rata } n \text { - } \\
\text { gain }\end{array}$ \\
\hline Kelas G semester 3 & 25 & 100 & 0,58 & 0,75 & 0,70 \\
\hline
\end{tabular}

Berdasarkan data yang diperoleh pada tabel 4.9 dapat dilihat skor minimum, skor maksimum, dan rata-rata $n$-gain. Hasil skor minimum dari pretest dan posttest adalah 0,58 dan skor maksimum dari pretest dan posttest adalah 0,75 sedangkan rata-rata $n$-gain dari pretest dan posttest adalah 0,70. Hasil data tersebut termasuk ke dalam kategori efektivitas tinggi.

\section{Tahap Evaluasi (Evaluation)}

Peneliti melakukan evaluasi dengan cara menganalisis data hasil dari penelitian yaitu analisis kebutuhan, penyusunan desain produk, validasi materi dan media dari para ahli, dan hasil angket respon mahasiswa. Tahap evaluasi dilakukan di semua tahapan. Tahap evaluasi berhenti setelah diperoleh hasil akhir dan modul transformasi linear telah mempunyai kriteria yang sangat menarik maka modul dapat digunakan pada proses perkuliahan Aljabar Linear.

Adapun kelebihan dari modul transformasi linear yang dikembangkan, yaitu sebagai berikut:

a. Modul transformasi linear ini berperan sebagai penuntun bagi mahasiswa untuk belajar secara mandiri di luar perkuliahan.

b. Modul ini dikembangkan berdasarkan model pembelajaran matematika Knisley yang bertujuan dalam proses perkuliahan dengan menggunakan pandangan learning as understanding dimana belajar akan lebih bermakna.

c. Mempermudah pendidik untuk menyampaikan materi pembelajaran karena materi yang disajikan terdapat materi dasar dan berhubungan dengan materi yang telah dipelajari sebelumnya.

Selain mempunyai kelebihan, modul transformasi linear terdapat beberapa kekurangan yang dapat diperbaiki dan dikembangkan kembali, yaitu sebagai berikut:

a. Modul dengan model pembelajaran matematika Knisley yang dikembangkan hanya mencakup satu materi pokok, tetapi dapat juga dikembangkan pada materi lainnya.

b. Modul transformasi linear ini dapat dikembangkan dengan model pembelajaran matematika yang lainnya. 


\section{SIMPULAN DAN SARAN}

Berdasarkan hasil penelitian dan pembahasan yang sudah dipaparkan, pengembangan bahan ajar berupa modul transformasi linear dengan model pembelajaran matematika Knisley telah divalidasi oleh ahli materi dan ahli media dengan kriteria valid dan hasil uji coba modul kepada mahasiswa prodi pendidikan matematika Universitas Islam Negeri Raden Intan Lampung memperoleh kriteria interpretasi sangat menarik serta pada uji efektivitas memperoleh hasil nilai n-gain dengan kategori efektivitas tinggi. Maka dari itu, disimpulkan bahwa pengembangan bahan ajar berupa modul transformasi linear dengan model Knisley dinyatakan layak, menarik, dan efektif untuk digunakan bagi mahasiswa dalam perkuliahan Aljabar Linear.

Beberapa saran yang dapat diberikan untuk pengembangan bahan ajar Aljabar Linear berupa modul dengan model pembelajaran matematika Knisley adalah perlu diperbaiki dan disempurnakan kembali jika hal demikian bermanfaat dan dapat menghasilkan produk yang lebih berkualitas, bahan ajar yang hanya menyajikan materi transformasi linear sehingga perlu dikembangkan pada materi lain dengan menyesuaikan kebutuhan mahasiswa dan kondisi kampus supaya kegiatan perkuliahan dapat berlangsung efektif dan lebih bermakna. Selain itu, uji coba modul dengan model pembelajaran matematika Knisley dalam kegiatan pembelajaran dapat dengan subyek penelitian yang berbeda.

\section{DAFTAR PUSTAKA}

[1] B. Luneto, "Profesionalisme Guru Dalam Perspektif Islam," J. Manaj. Pendidik. Islam, vol. 3, no. 1, hlm. 38-49, 2015.

[2] B. Ed. Course, Basic in Education. New Delhi: National Council of Educational Research and Training, 2014.

[3] H. B. Uno dan N. Lamatenggo, Landasan Pendidikan. Jakarta: Bumi Aksara, 2017.

[4] M. Hariyani, "Strategi Pembelajaran Matematika Madrasah Ibtidaiyah Berintegrasi Nilai-nilai Islam," Menara, vol. 12, hlm. 151, 2013.

[5] K. L. Purwanti, "Perbedaan Gender Terhadap Kemampuan Otak Kanan Pada Siswa Kelas I," SAWWA, vol. 9, hlm. 107-122, 2013.

[6] E. Dedy, E. Mulyana, E. Sudihartinih, dan U. P. Indonesia, "Pengembangan Bahan Ajar Kalkulus Vektor Berdasarkan Model Pembelajaran Matematika Knisley Sebagai Upaya Meningkatkan Kompetensi," Pythagoras, vol. 7, no. 1, hlm. 101-112, 2012.

[7] M. Wena, Strategi Pembelajaran Inovatif Kontemporer. Jakarta: Bumi Aksara, 2016.

[8] A. S. Pamungkas, N. Mentari, dan H. Nindiasari, "Analisis Kemampuan Berpikir Reflektif Siswa SMP Berdasarkan Gaya Belajar,” Numer. J. Mat. Dan Pendidik. Mat., hlm. 69-98, Jun 2018.

[9] R. W. Y. Putra, N. Nurwani, F. G. Putra, dan N. W. Putra, "Pengembangan Desain Didaktis Bahan Ajar Materi Pemfaktoran Bentuk Aljabar pada Pembelajaran Matematika SMP," Numer. J. Mat. Dan Pendidik. Mat., hlm. 193-206, Des 2017.

[10] Punaji Setyosari, Metode Penelitian Pendidikan dan Pengembangan Edisi Keempat, IV. Jakarta: Prenadamedia Group, 2015. 
Numerical: Jurnal Matematika dan Pendidikan Matematika, Vol. 3 No. 1 Juni 2019, 43-62

Ria Anggraeni Syafnuri, Netriwati, Dona Dinda Pratiwi

[11] R. K. V. M. Pratami, D. D. Pratiwi, dan M. Muhassin, "Pengembangan Media Pembelajaran Matematika Berbantu Adobe Flash Melalui Etnomatematika Pada Rumah Adat Lampung," Numer. J. Mat. Dan Pendidik. Mat., hlm. 125-138, Des 2018.

[12] Sugiyono, Metode Penelitian Pendidikan Pendekatan Kuantitatif, Kualitatif, dan R\&D. Bandung: Alfabeta, 2016.

[13] K. P. I Made Tegeh, I Nyoman Jampel, Model Penelitian Pengembangan. Yogyakarta: Graha Ilmu, 2014.

[14] C. Choirudin, "Efektivitas Pembelajaran Berbasis Schoology," Numer. J. Mat. Dan Pendidik. Mat., hlm. 101-126, Des 2017. 
Numerical: Jurnal Matematika dan Pendidikan Matematika, Vol. 3 No. 1 Juni 2019, 43-62

Ria Anggraeni Syafnuri, Netriwati, Dona Dinda Pratiwi

[Halaman ini sengaja dikosongkan] 